\title{
Anti-EGFR Monoclonal Antibody GC1118
}

National Cancer Institute

\section{Source}

National Cancer Institute. Anti-EGFR Monoclonal Antibody GC1118. NCI Thesaurus. Code C120316.

A recombinant, human monoclonal antibody directed ag ainst the epidermal growth factor receptor (EGFR) with potential antineoplastic activity. Upon intravenous administration, GC1118 binds to and blocks the lig and binding site of EGFR, which prevents receptor dimerization and activation. This may lead to an inhibition of both EGFR-dependent downstream pathways and EGFR-dependent tumor cell proliferation and metastasis. EGFR, a receptor tyrosine kinase, may be overexpressed on the surfaces of various tumor cell types. 